\title{
COMPOSITE MATERIALS FOR WARSHIP CONSTRUCTIONS
}

\author{
Lesław Kyziol \\ Gdynia Maritime University \\ Faculty of Marine Engineering \\ Morska Street 81-87, 81-225 Gdynia, Poland \\ e-mail:l.kyziol@wm.umg.edu.pl
}

\begin{abstract}
The article presents the basic properties of composite materials used for the construction of special ships. Static and dynamic characteristics of materials such as wood and polyester-glass composites are presented. Noteworthy are materials such as surface modified wood and polyester-glass composites with the addition of recyclate. Composite materials are widely used materials for the construction of non-magnetic warships. The article describes the properties of surface modified wood with polymethyl methacrylate and a polyester-glass composite with the addition of recyclate. The recyclate is fragmented, milled polyester-glass scrap. The content of the recyclate greatly affects the mechanical properties of the composite. The properties of the composite with the addition of recyclate depend on the recyclate content as well as the production technology and size of the recycled granulates. The test results showed that the increase in the recycled content causes a decrease in the mechanical properties of the composite. However, it should be remembered that these materials originated from waste, waste that is not subject to self-degradation, which have a very negative impact on the natural environment. At present, where there is a very large pollution of the natural environment, the processing and management of huge amounts of composite waste is an essential goal. A significant amount of recyclate significantly reduces the mechanical properties of the composite; however, the same large amount of recycled material has been transformed and used. The manufactured material and its structural elements are still non-magnetic structures and can be used on a less loaded element. The choice of material for the construction of special ships elements is determined not only by its properties but also by knowledge, experience, method of processing, economic and technical risk.
\end{abstract}

Keywords: polyester-glass composites, recyclate, modified wood, non-magnetic warships isotropic

\section{Introduction}

Composite materials due to their properties are used for special non-magnetic warships. More and more modern technologies of manufacturing these materials mean that materials with properties that meet the requirements of the construction can be obtained. Composite materials used for the construction of anti-mine warships are currently the basic material for building such units in some countries. Among the composite materials, polymer composites with high corrosion resistance, ease of forming, absorption of mechanical vibrations and in the case of anti-mine warships are non-magnetic. All components: hull, superstructure, drive system must be made of non-magnetic materials so that the warship is fully non-magnetic. Such materials are: nonmagnetic steel, polyester-glass composites (KPS), wood, modified wood. These materials have a common property - non-magnetic, but exhibit different strength properties, different specific weight, different way of making them, different way of making individual elements as well as different costs of maintenance, repair, etc. All this requires a full analysis in terms of knowledge concerning the construction of a given material, experience and striving for the implementation of state-of-the-art technologies leading to the development of the shipbuilding industry. The article [1] presents requirements and characteristics of materials used for non-magnetic warships.

In this article, particular attention was paid to the possibility of using surface modified wood and a polyester-glass composite with the addition of recyclate for marine non-magnetic constructions. 


\section{Hulls of special warships}

The representatives are hulls made of polymer composites. In the 1960s, plastic materials were used to build special warships. In Poland in the 1980s, the technology of construction of nonmagnetic ships made of plastic based on polyester-glass composites was developed. The project marked 207 was one of the first projects in the world, on the basis of which the plastic warship was built completely (except for the propulsion system) [2].

Polyester-glass composites are the most widely used material in the construction of anti-mine warship [3-7]. The hulls of these ships may have a massive or sandwich construction [8-10]. Massive structure made of polyester-glass composites (KPS), there is no system of rib of ship stiffeners. KPS strength depends on the type of resin, the proportion and type of glass reinforcement used the production process and load direction. KPS is resistant to corrosion - it requires sealing to prevent absorption of water [10]. Currently, superstructures, decks, bulkheads, advanced mast systems, propellers and shafts, rudders, pipes, pumps, valves, machines and other equipment on large warships, such as frigates, aircraft carriers and submarines, are built from composite materials [11]. An important disadvantage of ships with hulls from KPS is the need to conduct destructive tests of material. The laminated hull can only be assessed on samples made with structural elements. Composite hulls do not require much maintenance. Most often minor repairs can be carried out by the crew. Due to environmentally harmful stacks of plastic waste, including polyester-glass composites, it was decided to develop process and use polyester-glass scrap for the production of new composites. The method of production, technology and research on new polyester-glass composites are presented in many studies [12-16]. The research has shown that when processing waste from polyester-glass composites, it is possible to obtain a construction material that can be used, among others, on elements of the construction of special warships.

Table 1 shows examples of the results of mechanical tests of polyester-glass composite with the addition of recyclate in the amount of $10-30 \%$.

Tab. 1. Mechanical properties of the composite

\begin{tabular}{|l|c|c|c|}
\hline \multicolumn{1}{|c|}{ Composite } & $\begin{array}{c}E, \\
\mathrm{MPa}\end{array}$ & $\begin{array}{c}R_{m}, \\
\mathrm{MPa}\end{array}$ & $\begin{array}{c}\varepsilon, \\
\%\end{array}$ \\
\hline without recyclate & 7357 & 108 & 2.00 \\
\hline $10 \%$ recyclate & 7123 & 82 & 1.91 \\
\hline $20 \%$ recyclate & 4225 & 41 & 1.44 \\
\hline $30 \%$ recyclate & 4097 & 25 & 0.85 \\
\hline
\end{tabular}

Table 2 shows examples of the results of toughness tests of polyester-glass composite with the addition of recyclate in the amount of $10-20 \%$. The properties of the composite with the addition of recyclate depend not only on the recyclate content but also on the production technology and the size of the recycled granulate [14]. The test results contained in Tab. 1 and 2 showed that the increase of recyclate causes a decrease in the mechanical properties of the composite. However, the high mechanical properties of the material are always the most important. These materials originated from wastes that are not subject to self-degradation, which have a very negative impact on the natural environment. Nowadays, the purity of the natural environment should be sought. A large amount of recyclate reduces the mechanical properties of the composite; however, the same large amount of recycled material has been transformed and used. The manufactured material and its structural elements are still non-magnetic structures and can be used on a less loaded element [15].

Another material for the construction of anti-mine warships is wood, including modified wood. The development of science and technology has caused many defects in the wood to be eliminated, making wood a material that can be applied to a greater extent. It has been possible to reduce the 
absorbability of wood by seawater 5 times, which led to a significant increase in the mechanical parameters of this material [17]. The largest warship whose hull was made of wood is the German warship for detecting mines "Walter von Ledebur" with a length of $63 \mathrm{~m}$ [9].

Tab. 2. Toughness of the composite

\begin{tabular}{|l|c|}
\hline \multicolumn{1}{|c|}{ Composite } & $\mathrm{U}$ \\
\hline \multicolumn{1}{|c|}{$\mathrm{kJ} / \mathrm{m}^{2}$} \\
\hline without recyclate & 84.9 \\
\hline $10 \%$ recyclate & 59.5 \\
\hline $20 \%$ recyclate & 31.2 \\
\hline
\end{tabular}

In the United States of America, was built a new class of minesweeper with laminated timber with a displacement of over $1000 \mathrm{t}$ and a length of $68 \mathrm{~m}$ [8]. The construction of the hull made of wood is completely glued, and the hull plating has a thickness of $60 \mathrm{~mm}$ due to its strength. For the construction of ships, the natural properties of wood were basically used.

Technical progress has led to the development of technologies enabling the production of modified wood. Natural wood subjected to saturation with appropriate monomers followed by polymerization has obtained a significant increase in properties, especially strength properties. This wood is called modified wood $[18,19]$. The increase of strength and technological properties means that this material can be used to build complex ship structures. Good wood for ship hulls (mahogany, teak) is expensive, but it can be replaced with modified wood [10]. The basic advantages for the use of wood, especially modified wood for the construction of anti-mine warships hulls are its immunity, good thermal insulation, low specific weight in relation to metals, damping of sounds and vibrations, renewal, ease of machining and joining [1, 20-23].

Due to the much lower specific weight of natural/modified wood than polyester-glass composites, timber hulls may be lighter.

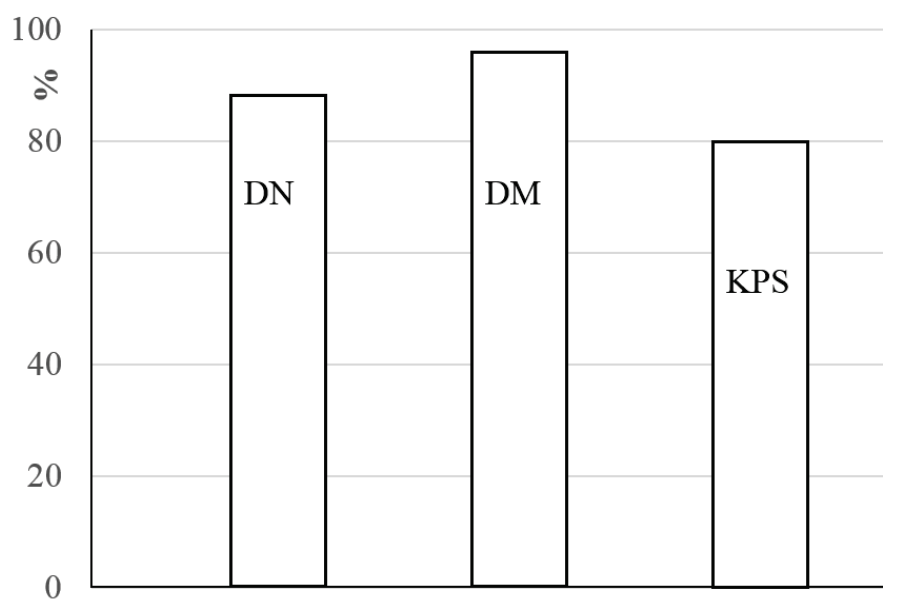

Fig. 1. Masses of hulls of the anti-mine warships: DN-natural wood, DM-modified wood KPS-polyester-glass composite [7, 21]

Figure 1 shows compares the masses of non-magnetic hulls of warships. Another very important parameter characterizing the usefulness of the material for the non-magnetic hulls of warships is the maximum deflections of similar hulls of warships from various materials. The deflection results of the hulls are shown in Fig. 2, and the analysis was made in [9]. Deflections of the wooden hull are more than twice as large as the hull of steel. This requires the use of special means to make the shaft line more flexible and that these measures should stiffen the bases of cannons and armament [9]. 
Deflection of the hull from natural wood can be reduced by about $30 \%$ as a result of the use of modified wood. In bending elements, maximum stresses occur in the extreme layers. Therefore, it is enough to strengthen only the external surfaces of the material. Surface modification of the wood significantly increases the strength and slightly reduces the stiffness of the wood.

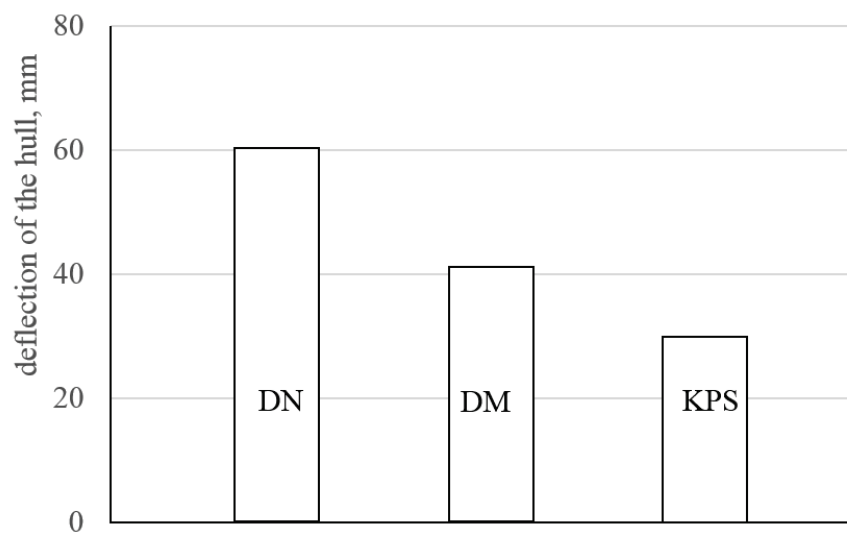

Fig. 2. Deflection of comparable hulls of non-magnetic warships [7, 21]

Studies on the influence of surface modification of wood on plate deflection, showed an uneven distribution of stresses in the "weak and strong" layers of wood - Fig. 3.

a)

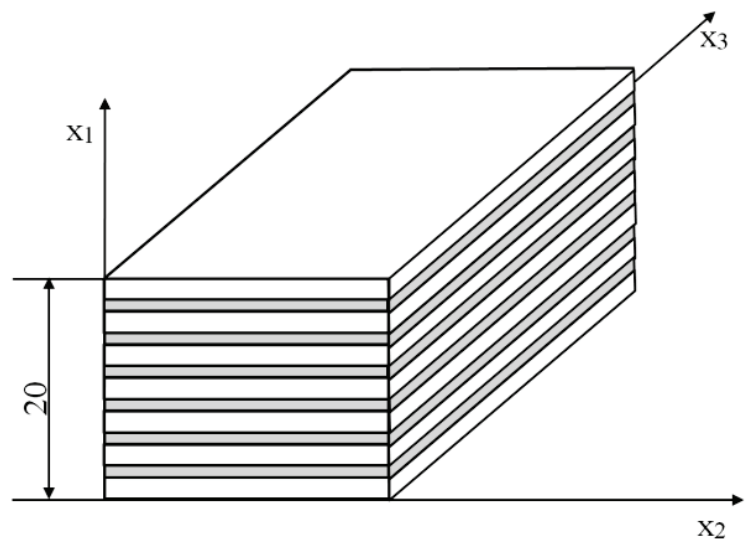

b)

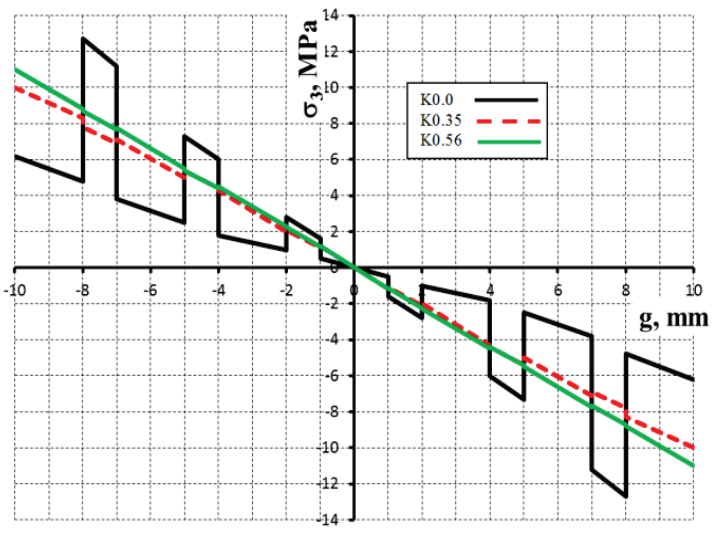

Fig. 3. Configuration a) outer layers - soft wood, b) stress distribution after the thickness of a natural wood panel K0.0 and modified K0.35 and K0.56 [24]

The layers of weak wood are strengthened, these layers take on the partial loads from the layers of strong wood and in this way, the stress distribution is evenly balanced [17].

Figure 4 presents selected mechanical parameters of polyester-glass composite, natural and modified wood. It can be observed that the strength properties of polyester-glass composites are comparable to those of surface-modified wood.

\section{Conclusions}

Wood and polyester-glass composites meet the requirements for hulls for anti-mine warships. In the construction of non-magnetic warships, modified wood deserves attention. This material exhibits much higher mechanical properties than natural wood, which knowledge and experience in the construction of ship hulls is very high. This material can find its place not necessarily as a material for the construction of the hull, but for various components of the non-magnetic warship. Low absorbability and a significant increase in strength properties, the known and simple processing of this material indicates the use of this material for marine constructions. In addition, 
when constructing this type of construction, which is a warship to combat mines, the hull construction costs account for approximately $25 \%$ of the total warship costs. That is why economic, technical and constructional factors are very important, which require in-depth analysis and knowledge.
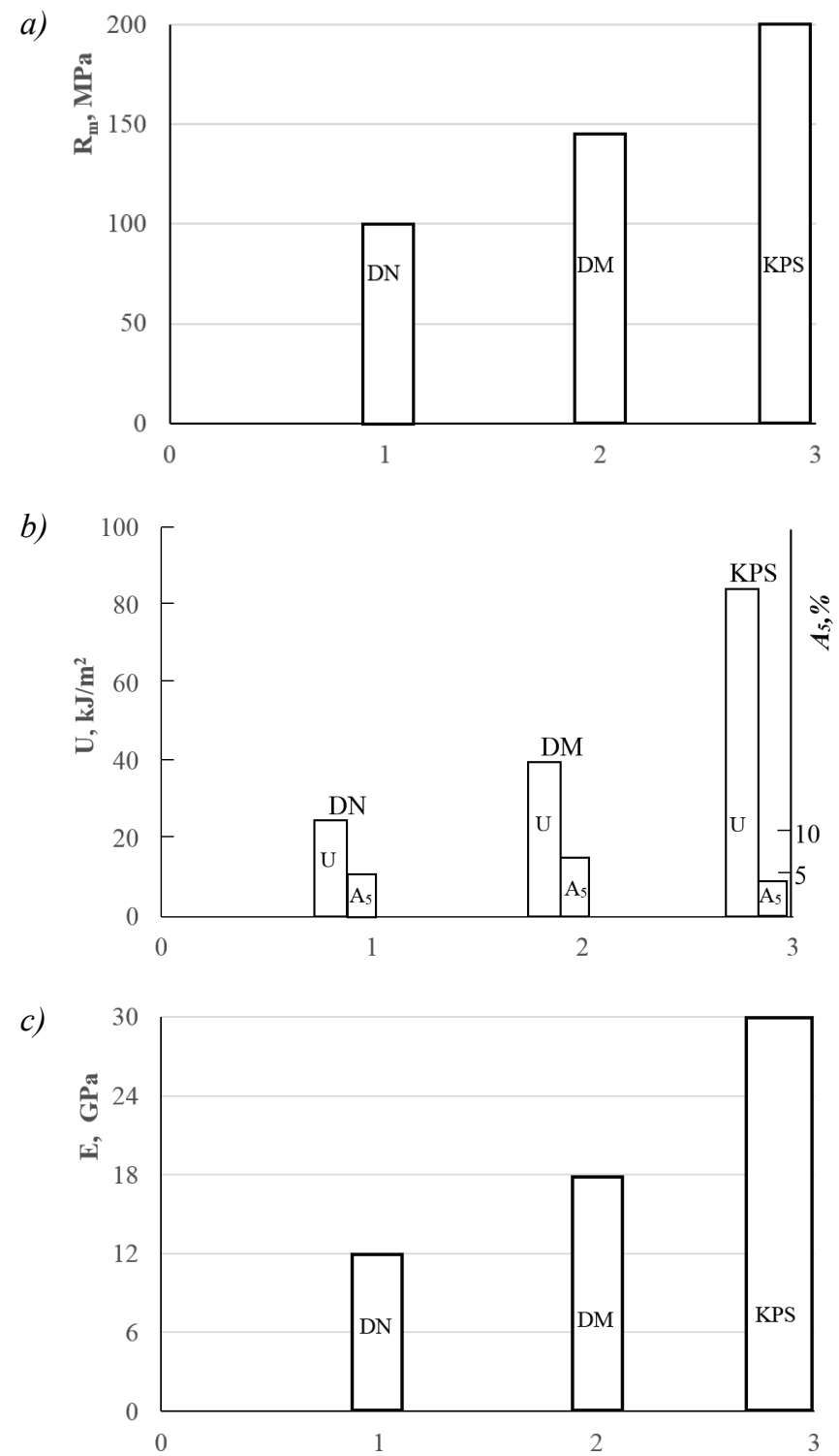

Fig. 4. Comparison of mechanical properties of polyester-glass composite, natural, and modified wood $R_{m}$-tensile strength, $U$-toughness, $E$ - modulus of elasticity, $A_{5}-\operatorname{strain}[10,22]$

\section{References}

[1] Kyzioł, L., Możliwości zastosowania drewna modyfikowanego na okręty przeciwminowe, Logistyka, 3, pp. 2740-2749, 2015.

[2] http://www.magnum-x.pl/artykul/indyk-z-gdyni.

[3] Gibson, G. R., Construction and sea trials plastic mine counter-measures vessel, Transactions the Institute of Marine Engineers, Vol. 93, Paper 7, 1981.

[4] Lankford, B. W., Angerer, J. F., Glass reinforced plastic developments for application to minesweeper construction, Naval Engineers Journal, October 1971.

[5] Smith, C. S., Pattison, D., Design of structural connections in GRP ship and boat hulls, C230/77, Conference on Designing with Fiber Reinforced Materials, London, September 1977. 
[6] Zaczek, Z., Zalety $i$ wady kadlubów okrętowych z tworzyw sztucznych, Przegląd Morski, $\mathrm{Nr}$ 9, 1977.

[7] Zaczek, Z., Perspektywy rozwojowe trałowców o kadtubach z tworzyw sztucznych, Przegląd Morski, Nr 11, 1977.

[8] Dawson, Ch., Construction materials for combat craft, Combat Craft, Vol. 2, No. 1, 1984.

[9] Schütz, H., Fochs, G., Non-magnetic materials -the basic criteria on the design of MCMvs, Maritime Defence, Vol. 9, May 1984.

[10] Zaczek, Z., Materiały konstrukcyjne do budowy okrętów przeciwminowych, Przegląd Morski, Nr 10, pp. 23-38, 1987.

[11] Mouritz, A. P., Gellert, E., Burchill, P., Review of advanced composite structures for naval ships and submarines, Composite Structures, Vol. 53, pp. 21-41, 2001.

[12] Kyzioł, L., Jastrzębska, M., Określenie wybranych właściwości mechanicznych odpadowych materiałów kompozytowych, Logistyka, 3, pp. 2758-2763, 2015.

[13] Kyzioł, L., Analiza możliwości zastosowania materiałów kompozytowych na konstrukcje okrętów specjalnych, Autobusy, Technika, Eksploatacja, Systemy Transportowe, 6, pp. 846850, 2017.

[14] Hajdukiewicz, G., Panasiuk, K., Kyzioł, L., Resistance to aging research in sea water composites with the polyester-glass recyclate, Journal of KONES Powertrain and Transport, Vol. 25, No. 3, pp. 219-225, 2018.

[15] Kyzioł, L., Panasiuk, K., Hajdukiewicz, G., The influence of granulation and content of polyester-glass waste on properties of composites, Journal of KONES Powertrain and Transport, Vol. 25, No. 4, pp. 223-229, 2018.

[16] Panasiuk, K., Kyzioł, L., Hajdukiewicz, G., Analysis of the cracking process of layered composites with polyester-glass recyclate using dynamic tests, Scientific Journals of the Maritime University of Szczecin, 57 (129), pp. 73-78, March 2019.

[17] Kyzioł, L., Drewno modyfikowane na konstrukcje morskie, AMW, Gdynia 2010.

[18] Kyzioł, L., Możliwości wykorzystania tworzyw kompozytowych do wałów okrętowych, Zeszyty Naukowe Akademii Morskiej w Gdyni, Nr 93, pp. 71-85, 2016.

[19] Lankford, B. W., Angerer, J. F., Glass reinforced plastic developments for application to minesweeper construction, Naval Engineers Journal, October 1971.

[20] Kowalski, S. J., Kyziol, L., Rybicki, A., Composite of wood and polymerized methacrylate, Composities, Part B, Vol. 33, pp. 77-86, 2002.

[21] Krzysik, F., Nauka o drewnie, Wydanie II, PWN, Warszawa 1978.

[22] Ławniczak, M., Walentynowicz, T., Lignomer - właściwości i zastosowanie, PWN, Rolnicze i Leśne, Poznan 1979.

[23] Ławniczak, M., Widłak, H., Badania zmierzajace do ustalenia przydatności lignomeru na podłogi $w$ wagonach towarowych, Materiały konferencyjne, Modyfikacja Drewna, s. 243-267, AR Poznan 1981.

[24] Kyzioł, L., Reinforcing wood by surface modification, Composite Structures, Vol. 158, pp. 64-71, 2016.

Manuscript received 16 August 2019; approved for printing 17 December 2019 